\title{
Landscape Integrated Soil and Water Conservation (LISWC) System for Sloping Landscapes in Atlantic Canada
}

\author{
Sheng Li
}

check for updates

Citation: Li, S. Landscape Integrated Soil and Water Conservation (LISWC) System for Sloping Landscapes in Atlantic Canada. Agriculture 2021, 11, 427. https://doi.org/10.3390/ agriculture 11050427

Academic Editors: Johann G. Zaller and John C. Tyndall

Received: 8 December 2020

Accepted: 6 May 2021

Published: 9 May 2021

Publisher's Note: MDPI stays neutral with regard to jurisdictional claims in published maps and institutional affiliations.

Copyright: (C) 2021 by the author. Licensee MDPI, Basel, Switzerland. This article is an open access article distributed under the terms and conditions of the Creative Commons Attribution (CC BY) license (https:/ / creativecommons.org/licenses/by/ $4.0 /)$.
Fredericton Research and Development Centre of Agriculture and Agri-Food Canada, P.O. Box 20280, Fredericton, NB E3B 4Z7, Canada; Sheng.Li@Canada.CA; Tel.: +1-506-460-4467

\begin{abstract}
Soil and water are fundamental and precious resources for agriculture. In Atlantic Canada (AC), intensive agricultural production systems have led to detrimental environmental effects such as soil erosion and the contamination of receiving waters, posing significant threats to the resilience and sustainability of the agro-ecosystem. Although many beneficial management practices (BMPs) have been developed, they all have their shortcomings and there are often trade-offs for each individual BMP. In this paper, a new paradigm is proposed for soil and water conservation-landscape integrated soil and water conservation (LISWC), a system designed to conserve and reuse soil and water within the landscape by integrating multiple BMPs based on an understanding of the landscape processes and knowledge about the BMPs. On a typical sloping field in AC, an LISWC system can be established by integrating BMPs such as diversion terraces and grassed waterways, tile drainage, water retention structures, supplemental irrigation, conservative tillage practices and soil-landscape restoration. Each individual BMP is designed to enhance one aspect of soil and water conservation but working on their own, they are all insufficient for the landscape as a whole and sometimes even have negative impacts. However, once integrated in the landscape, they complement each other: water erosion is reduced by diversion terraces and grassed waterway and conservative tillage, field drainage condition is enhanced by tile drainage, runoff and tile drained water is stored in the retention structure and reused for irrigation, and most eroded soil is returned to the soil loss area with soil-landscape restoration. This holistic landscape perspective can be used to develop LISWC systems for other landform types or applied at watershed or regional scales. Future studies are needed for the connections and interactions between individual BMPs, and analysis on the overall economic benefit of an LISWC system.
\end{abstract}

Keywords: LISWC; BMP; landscape position; integration

\section{Introduction}

Atlantic Canada (AC) features a humid continental climate, hilly landscapes and soils developed from glacial till parent materials [1]. The climate and soil conditions have supported high quality rainfed potato production systems (potato typically rotates with cereal and forage crops in multi-year cycles), making potato the dominant cash crop in AC for the past century [2-4]. However, potato production requires intensive management, typically associated with a high disturbance of soil and high inputs of fertilizers and pesticides. As a result, agricultural fields in AC are subject to strong soil erosion, particularly water and tillage erosion [5-7]. The risk of losing fertile soil due to erosion poses a significant threat to soil health and, therefore, is of great concern to landowners. On the other hand, sediment, nutrients, and other chemicals and pathogens carried by runoff water may enter the surface- and ground-water systems, and those moved by wind may enter the atmosphere, affecting water and air quality. In recent years, despite improvements in fertility and disease control, potato yield in AC has been stagnant [8]. Many researchers have attributed the limitation in potato yield to the declining soil health and high variability in weather conditions in this region [9-12]. 
Another challenge the agricultural industry is facing in this region is water management. Annual precipitation in AC and much of northeast USA is approximately 1100 to $1200 \mathrm{~mm}$, whereas annual evaporation varies from 400 to $500 \mathrm{~mm}$ [13]. The amount of natural water supply generally meets the requirement for potato growth and, therefore, this area is dominated by rainfed agriculture [2]. However, precipitation is not evenly distributed in time and space. There are dry periods in the growing season and there are areas more prone to drought conditions than other areas. Climate change adds onto these uncertainties. It has been predicted that with climate change, in $\mathrm{AC}$, the average temperature will rise but the trend in average precipitation is uncertain [14,15]. Rising temperatures will increase evapotranspiration and potentially will result in more water deficit. In addition, for both temperature and precipitation, there is a high confidence that their variabilities will increase due to climate change. This means that there will be more extreme weather events such as intensive rainstorms and long drying periods. Overall, agriculture in AC will likely experience less temperature stress but more severe water stress in the future.

To meet these rising challenges, there is an urgent need for effective beneficial management practices (BMPs) to conserve soil and water. Many soil and water conservation BMPs have been adopted, developed and implemented in AC and studies have been carried out to examine their effectiveness. For example, a group in the Fredericton Research and Development Centre (FDRC) of Agriculture and Agri-Food Canada (AAFC) examined the effectiveness of stone removal and stone crushing, tile drainage and diversion terraces and grassed waterway systems (DTGWs) on their designed functions [16,17]; Bélanger et al. $[9,18]$ examined the effects of supplemental irrigation and $\mathrm{N}$ fertilizer on potato yield and tuber quality. Other BMPs evaluated in this region include fertilizer management, crop rotation, and different tillage operations $[12,19,20]$. Overall, these past studies suggest that most BMPs are effective in solving their targeted problems. However, there are often unexpected "trade-offs" or limitations for a given BMP. For example, the DTGW system can effectively reduce water erosion on sloping land [17] but it can make the field too wet in wet years [21]. Tile drainage is widely used in AC to cope with soil waterlogging conditions in spring and autumn but there is a great concern that tile drainage creates an easy path for nutrient leaching [22]. Supplemental irrigation reduces crop water stress, but it can negatively affect the environment if the capacity of readily available water source is limited [23]. Conservation tillage has been adopted for erosion control, but study has shown that although it may effectively reduce water erosion, its effects on tillage erosion control is limited [24]. Obviously, no BMP is a silver bullet that can solve all problems.

The limitations of individual BMPs have been recognized worldwide. Following the philosophy of systematic conservation planning, which was famously promoted by Margules and Pressey [25-27], efforts have been made to stack multiple BMPs [28,29] and methods have been developed to select most appropriate BMPs or to optimize the placement of BMPs spatially [26,30-33]. For example, Srivastava et al. used the AnnAGNPS model and a genetic algorithm to optimize BMP selection on a field-by-field basis for an entire watershed [30]. Maringaniti et al. developed a multi-objective optimization tool for the selection and placement of BMPs for nonpoint source pollution control [31]. However, these studies were mostly conducted at the watershed scale. The goal was often limited to maximizing the effectiveness BMPs or reducing the costs of BMPs to solve a specific environmental issue (e.g., nutrient losses). As pointed out by Tomer and Locke [34] and Tomer et al. [28], there is still a lack of integration for BMPs at the landscape level and BMP application is often disconnected to the complexity of hydrologic dynamics and pathways of nutrient and sediment loss. More importantly, many BMPs were designed to remove water and sediment as waste or pollutants without realizing that they are fundamental and precious resources for agriculture.

With the goal of conserving soil and water within the landscape, our objective is to design a system that integrates multiple BMPs in a landscape context so that the shortcomings of individual BMPs are minimized and benefits at the landscape level are maximized. In 
this paper, we first summarize landscape positions and landscape processes to lay out the landscape context and then briefly describe some selected BMPs, their designed functions and limitations. With this basic knowledge on landscape and BMPs, we introduce the concept of LISWC, a system designed to integrate multiple BMPs in a landscape context, and then discuss the landscape perspective, the implementation of LISWC in different landforms and scales, and the directions for future research.

\section{Landscape Positions and Landscape Processes}

It has long been recognized in soil science that soil processes, especially soil formation, need to be studied from a landscape perspective. Milne [35] examined soil development along a hillslope and found that topographic context determines some key soil forming processes and leads to a distinctive, repeated suite of soil taxonomic units (termed soil catena) along the hillslope. Considering a hydrological path along a hillslope, for any given point on the hillslope, its relative position in the hillslope is a controlling factor that determines the redistribution of water, solutes, and sediments. As hydrologic conditions can influence many landscape processes, landscape position also to a large degree determines some microclimate parameters (e.g., soil temperature) and soil biophysical properties (e.g., soil depth and color). More broadly, there are interlinked spatial and functional relationships between landform elements along a topo-sequence and such relationships are the foundation for many soil-landform models [36].

The landscape perspective can be demonstrated with the hydrology and soil erosion processes along a hillslope (Table 1). During a runoff event, surface runoff is initiated close to the top of the slope [37]. Runoff amount and flow speed gradually increase in the upper-slope and middle-slope segments and usually reach the plateaus somewhere in the lower-slope segment, where slope gradient is significantly reduced. Subsurface flow is mainly vertically downward in the upper-slope segment and lateral flow is small and slow. In the middle-slope segment, vertical downward flow is still dominant but there is usually a noticeable amount of lateral subsurface flow in a runoff event. Lateral subsurface flow continues to build up its strength towards lower-slope and in large runoff events, it may seep out to the surface and become surface flow. The depression segment is located at the bottom of the slope so that both surface and subsurface flow accumulate there. Surface runoff usually arrives before subsurface flow in a runoff event, causing a vertical downward movement at first in the depression area. As the runoff event progresses, subsurface flow starts to reach the depression area and when the amount is significant enough, subsurface flow will be pushed up vertically to the surface. Water erosion is mainly driven by surface runoff, so it follows a similar spatial pattern as surface runoff $[37,38]$. Typically, water erosion gradually increases down the slope until it reaches the highest rate, usually somewhere in the middle-slope or upper lower-slope segment, and then it gradually decreases (Table 1). Towards the end of the lower-slope segment or in the depression areas, water-induced soil accumulation may occur. For tillage erosion, soil loss typically occurs in the upper-slope segment (often convex or on the downslope side of a field boundary) and soil accumulation occurs on the lower-slope and depression segments (often concave or on the upslope side of a field boundary) [39-41]. The middle-slope segment usually serves as a transition zone, with a high amount of soil translocation by tillage, but no net soil gain or soil loss. The spatial pattern of wind erosion is similar to that of tillage erosion, but it is usually asymmetric, with soil loss typically occurring on the windward side of the slope and soil accumulation on the leeward side of the slope.

Knowledge on these landscape processes at different landscape positions is critical for understanding how the soil and water conservation BMPs work, as BMPs are mostly designed to intervene or regulate one or more of these landscape processes at specific landscape positions. 
Table 1. Generalized topographic and hydrologic characters and erosion patterns for different landscape positions (revised based on [31]).

\begin{tabular}{ccccc}
\hline & \multicolumn{3}{c}{ Landscape Position } \\
\cline { 2 - 5 } & Upper-Slope & Middle-Slope & Lower-Slope & Depression * \\
\hline Field boundary & Downslope side & Not adjacent to & $\begin{array}{c}\text { Upslope side or not } \\
\text { adjacent to }\end{array}$ & $\begin{array}{c}\text { Upslope side or not } \\
\text { adjacent to }\end{array}$ \\
Slope gradient & Low & High & Low & Near level \\
Slope curvature & Convex & Linear & Concave & High concave \\
Surface runoff & Slow & Fast & Fast to slow & Not flowing or very slow \\
Subsurface flow & Vertical, down & Vertical and lateral, & Lateral and vertical, down & Vertical, down to up \\
Water erosion & Low loss & digh loss & Loss or accumulation & High accumulation \\
Tillage erosion & Loss & Balanced & Accumulation & High accumulation \\
Wind erosion $* *$ & Loss & Low loss or & Low loss or accumulation & High accumulation \\
\hline
\end{tabular}

* Some landscapes may not have the depression segment and some depressions may locate in the middle of a field. ** Pattern of wind erosion is primarily driven by the prevailing wind direction and is normally asymmetric with soil loss on the windward middle-slope to upper-slope areas and soil accumulation on the leeward middle-slope to lower-slope areas.

\section{Individual BMPs}

\subsection{Diversion Terraces and Grassed Waterway (DTGW) System}

The DTGW system is one of the most popular BMPs used for water erosion control on fields with long and steep slopes. In a DTGW system, earth berms are built along the contour lines (with a slight angle to shed water) to divide a long slope into shorter segments (terraces), thus preventing surface runoff from building up its energy and momentum, reducing its erosive power. Runoff is directed into waterways that are planted with grass to prevent the formation of gullies and allow water infiltration and the settlement of eroded soil particles $[17,42]$. The DTGW system has proven to be an effective BMP for water erosion control. Chow et al. [21] reported that at the field scale, it can reduce runoff and soil loss by $87 \%$ and $95 \%$, respectively, on their sites in AC. At the watershed scale, longterm monitoring data in the Black Brook Watershed in the province of New Brunswick, Canada, suggests that when the area protected by DTGW in the watershed increased by one hectare, there was a $9 \mathrm{Mg}_{\text {year }}{ }^{-1}$ decrease in sediment yield at the watershed outlet $[20,43]$. However, DTGW slows down surface drainage, which may result in fields being too wet in wet years [21]. Additionally, it may encourage subsurface and groundwater flow and, therefore, increase nutrient losses through subsurface pathways. As such, it may increase the risk of groundwater contamination [44]. Moreover, on a sloping field, tillage erosion often causes soil loss on the downslope side of a tillage boundary and soil accumulation on the upper-slope side of a tillage boundary $[39,40]$. Earth berms added in a DTGW field create boundaries for tillage operations and, therefore, DTGW can increase tillage erosion $[41,45]$.

\subsection{Tile Drainage}

Tile drainage is often used for water table management in lowland areas where water table is high [42]. However, it is increasingly being used in areas with poor internal drainage or with temporarily perched water table. In AC, basal till soil underlain with dense, compact subsoil or parent materials of low permeability is a widespread problem. Nowland [46] estimated over 32\% of arable lands in AC are affected by impermeable subsoils. Slow drainage results in excessive wetness, particularly during spring and autumn. The wet soil conditions limit field trafficability, delay tillage operations and seedbed preparation, and sometimes lead to yield losses [47]. For potatoes in particular, prolonged conditions of excess water in soil profile can cause root damage, seed piece decay, delayed emergence, disease problems, a brown center and hollow heart, as well as tuber quality and storage problems [48]. To remove excess water from the soil profile, tile drainage has 
long been adopted in AC and has been progressing rapidly since the late 1970s [49,50]. Tile drainage brings many agronomic, hydrologic, economic, and environmental benefits such as increasing soil temperature, infiltration, water storage capacity, field trafficability, and crop yield, and reducing soil waterlogging, soil compaction, soil erosion, peak flow, and $\mathrm{P}$ and $\mathrm{K}$ losses [51]. However, tile drainage provides a shortcut for water flowing from fields to the surface water systems and, therefore, may increase water contamination with substances such as $\mathrm{N}$ and pesticides in dissolved forms $[22,52,53]$. In addition, tile drainage also exports fine grained soil particles and, in some cases, can be a major pathway for sediment and $\mathrm{P}$ transport from agricultural fields to receiving waters [54-57]. As a result, managing outflow from drainage tiles has become a great concern and a hot topic for research in recent years [58].

\subsection{Water Retention Structure (WRS)}

Wet water retention ponds, dry detention ponds and wetlands have long been used in both urban and agricultural settings to manage storm water runoff [59]. By retaining runoff water, these WRSs can retain substances dissolved in water and are effective in reducing peak flow, thus preventing flooding and downstream erosion [60]. More effectively, WRSs retain soil particles (sediment) eroded from upslope catchment areas together with nutrients and other chemicals attached to these soil particles. As a result, WRSs are effective in improving water quality in downstream water systems [29,59,61]. However, building a WRS is expensive, and space needed for building a WRS means taking land out of production; both induce costs for the landowners. Additionally, the storage capacity of a WRS is limited. Once the storage capacity is reached, the WRS is no longer able to restore additional water or sediments. Most WRSs have a spill way, designed to shed water when water in the WRS reaches its storage capacity. Due to continuous sediment detention, it is inevitable that the WRS will be filled with sediment over time, gradually reducing its water storage capacity. To maintain its function, accumulated sediment must be excavated after a certain period of time. This ongoing maintenance cost can be significant in some cases. With all these costs associated with a WRS, if the benefits are only downstream water quality improvement, there is little incentive for producers to adopt it as a BMP [20].

\subsection{Supplemental Irrigation}

Water deficit is one of the most important problems in semiarid and arid regions where irrigation is absolutely required for profitable crop productions [42]. In AC, however, annual precipitation is approximately $1100-1200 \mathrm{~mm}$, whereas annual evaporation varies from 400 to $500 \mathrm{~mm}$ [13]. Therefore, in general, irrigation is not necessary for potato and field crop productions [2]. Unfortunately, precipitation is not evenly distributed in time and space. There are dry periods in the growing season and there are areas in $\mathrm{AC}$ more prone to drought conditions than other areas. Water deficit can be a serious problem in dry years, especially for potato crop due to its relatively shallow root-zone depth [23,62]. Studies have shown that supplemental irrigation has the potential to increase potato yield and quality in $\mathrm{AC}[9,18,63]$. However, the economic gain is generally not enough to offset the cost for installing and operating the irrigation system [23]. On the other hand, technically, one major challenge for irrigation in AC is the lack of a reliable water source. Many fields are far away from surface water sources such as rivers and lakes. Tapping into groundwater is not only costly but also under strict regulation and scrutiny. Another concern for irrigation in AC is over irrigation. Weather sometimes is unpredictable. Occasionally, unexpected rainfall occurs following irrigation. On fields without a tile drainage system, this can make the soil too wet, turning a water deficit problem into a water excess problem, which may result in crop yield and quality losses as well as soil erosion and nutrient leaching [64]. Determining the timing and amount of water for irrigation remains one of the biggest knowledge gaps for supplemental irrigation in AC [18,23]. 


\subsection{Conservative Tillage Practices}

In agricultural fields, tillage is used for soil aeration, seed bed preparation, weed control, as well as soil moisture and temperature control, residue management, incorporating fertilizer and lime, and insect control [65]. For potato, hilling and harvesting also disturb large amounts of soil and can be considered as tillage operations as well. Intensive tillage operations have long been recognized as a major factor for accelerated water and wind erosion and a reason for soil degradation [66]. More recent studies have shown that due to in-field variations of soil movement by tillage equipment, tillage alone can cause uneven soil redistribution, resulting in a form of soil erosion termed tillage erosion [39-41]. Typical patterns of tillage erosion include soil loss from slope convexities (e.g., hilltops) and soil accumulation in slope concavities (e.g., depressions), soil loss from the down-side of a field boundary (i.e., fences, hedges, diversion terraces, etc.) and soil accumulation on the upper-side of a field boundary. Diversion terrace berms serve as field boundaries for tillage and, therefore, increase tillage erosion [41,45].

Many conservative tillage practices have been developed to reduce the negative impacts of tillage on soil. A relatively easy practice is contour tillage instead of up-downslope tillage. With up-down-slope tillage, a tractor is easier to operate than with contour tillage, especially on a steep slope because there is a higher risk for the tractor rolling over sideways with contour tillage than with up-down-slope tillage. However, the up-downslope furrows facilitate flow concentration thus increase surface drainage in channels and channelized water erosion. Additionally, tillage speed and depth are often different for upslope versus downslope tillage, resulting in high tillage erosion [67]. With contour tillage, ridges and furrows are oriented along the contour lines. They work as barriers for downslope water flow so that runoff and water erosion are reduced. Contour tillage also reduces variation in tillage speed and depth and thus reduces tillage erosion compared to up-down-slope tillage [68]. One drawback for contour tillage is that it may reduce surface drainage, so may not be ideal for fields with water drainage problems. Another popular conservative tillage practice is using conservation tillage equipment such as a chisel plough and direct seeder. The design of conservation tillage equipment is such that it leaves more crop residue on the soil surface than traditional tillage equipment does so that it protects the soil surface better from water and wind erosion. Conservation tillage equipment also generally causes less soil disturbance than conventional tillage equipment such as a moldboard plough. However, conservation tillage equipment does not work well with crops grown with a raised bed such as potato. The moldboard plough is still the predominant primary tillage equipment used for potato cropping in AC. Moreover, less soil disturbance does not necessarily mean lower tillage erosion. Research has shown that some chisel ploughs and direct seeders can be as erosive as a moldboard plough with regard to tillage erosion [24,67]. One way to reduce tillage erosion is to use a reversible moldboard plough and always throw soil upslope, a practice termed upslope-throw tillage $[31,68]$. By throwing soil to the upslope direction, it compensates the gravity-driven downslope soil movement and, therefore, reduces net downslope tillage translocation, thus, tillage erosion.

\subsection{Soil-Landscape Restoration}

Soil erosion causes the loss of fertile topsoil. However, eroded soil particles are mostly deposited within the field $[37,38]$. For tillage erosion, although it can be extremely high in some spots in the field, for the field as a whole, the net soil loss is zero. The eroded soil is simply redistributed and deposited somewhere else within the field [40,45]. For water erosion, soil loss is most severe at places where the slope gradient is high (e.g., middleslope). Where the slope gradient decreases (e.g., lower-slope and depression), water runoff speed decreases, so that its capacity for transporting soil particles is reduced. As a result, soil particles start to precipitate, leading to soil deposition [38].

Soil-landscape restoration is the practice of moving some of the accumulated soil from soil deposition areas back to soil loss areas $[68,69]$. This practice is particularly suitable for tillage erosion because tillage erosion is not selective with regard to particle size and does 
not break soil aggregates. The soil accumulated at deposition areas due to tillage erosion is fertile topsoil, whereas soil at the eroding areas is degraded. Returning the accumulated soil to the eroding spots of the field can potentially re-establish this soil to its original conditions. Given the pattern of tillage erosion, soil-landscape restoration practices include moving soil from slope concavities (e.g., depressions) to slope convexities (e.g., hilltops) and from the upper-side to the down-side of a field boundary. In a terraced field on a linear slope, typical soil-landscape restoration is to move soil from the bottom to the upper part of the terraces.

For water erosion, soil-landscape restoration is more complicated because water erosion is a selective process. The particles first deposited in a field are often the coarse particles while the fertile fine particles are carried further, and a large portion could be carried out of the field by runoff water into streams and waterways. Moreover, soil granules can be disaggregated into individual particles along the flow path. As such, returning in-field water deposited materials back to the eroding areas may not help much in restoring soil quality there [57]. However, in places where the speed of runoff water are sufficiently reduced, fine particles will also deposit. A good example is retention pond. When the retention pond is large enough, water flow through the retention pond is minimized so that particles, including those fine particles, will mostly be deposited at the bottom of the pond. Some large depressions and wetlands also function like retention ponds with regard to retaining water and sediments. As mentioned above, continuous sediment accumulation will reduce the storage capacity for a retention pond so that it is necessary to dig out the deposited materials periodically. Returning the excavated soil back to the eroding areas can be a follow up BMP to the regular maintenance with the benefits of restoring degraded soil due to soil erosion.

\section{The LISWC System}

It is clear that the six BMPs discussed above all have their strengths and weaknesses. A logical question is: can these BMPs be applied in the same field so we can obtain all the benefits while minimizing some of the drawbacks, and if yes, how? In AC and northeast USA, a dominant landform type is rolling landscape, which is characterized by long and steep slopes [70]. These slopes are mostly linear across the slope (i.e., without much variation along the contour direction). Therefore, a one-dimensional linear slope is a good representation for such a landscape (Figure 1a). On such a linear slope, an LISWC system can be established by integrating BMPs as follows: (1) build a DTGW system to control water erosion (Figure 1(b1)); (2) install drainage tiles to quickly remove excessive water (Figure 1(b2)); (3) direct surface and tile drained water into a WRS (e.g., a pond) to retain water, sediment and nutrients (Figure 1(b3)); (4) use the retained water for supplemental irrigation during dry periods (Figure 1(b4)); (5) apply contour and upslope-throw tillage to reduce water and tillage erosion (Figure 1(b5)); and (6) apply soil-landscape restoration by moving soil from the bottom to the upper part of a terrace and from the retention structure back to the eroded spots in the field to restore soil health at these eroded spots (Figure 1(b6.1 and 6.2)).

Based on our current knowledge about the landscape processes and how each BMP functions, the effects of such an LISWC system (Figure 1c) can be summarized as follows. The DTGW effectively reduces water erosion. It also forces tillage to be conducted in the contour direction which reduces both water and tillage erosion. The drawback of DTGW and contour tillage on causing excessive water condition and poor soil drainage is effectively compensated by tile drainage. The other drawback of DTGW on increasing tillage erosion is effectively compensated by upslope-throw tillage and soil-landscape restoration within a terrace. The drawback of tile drainage on enhancing nutrient losses is in turn effectively reduced by the retention pond. On the other hand, in this LISWC system, the benefit of the retention pond is no longer just improving water quality downstream. The water retained in the retention pond facilitates supplemental irrigation, which otherwise will have to find other water resources. Meanwhile, excavating accumulated sediment is no 
longer just to restore the capacity of the retention pond. Sediment and its attached nutrients, which otherwise will leave the field and cause contaminations in waterways, are used as soil modification materials to restore the degraded soil landscape to its original condition. Overall, by integrating multiple BMPs into such an LISWC system, the shortcomings of each individual BMPs are minimized or compensated so that the benefits for the landscape as a whole are maximized.

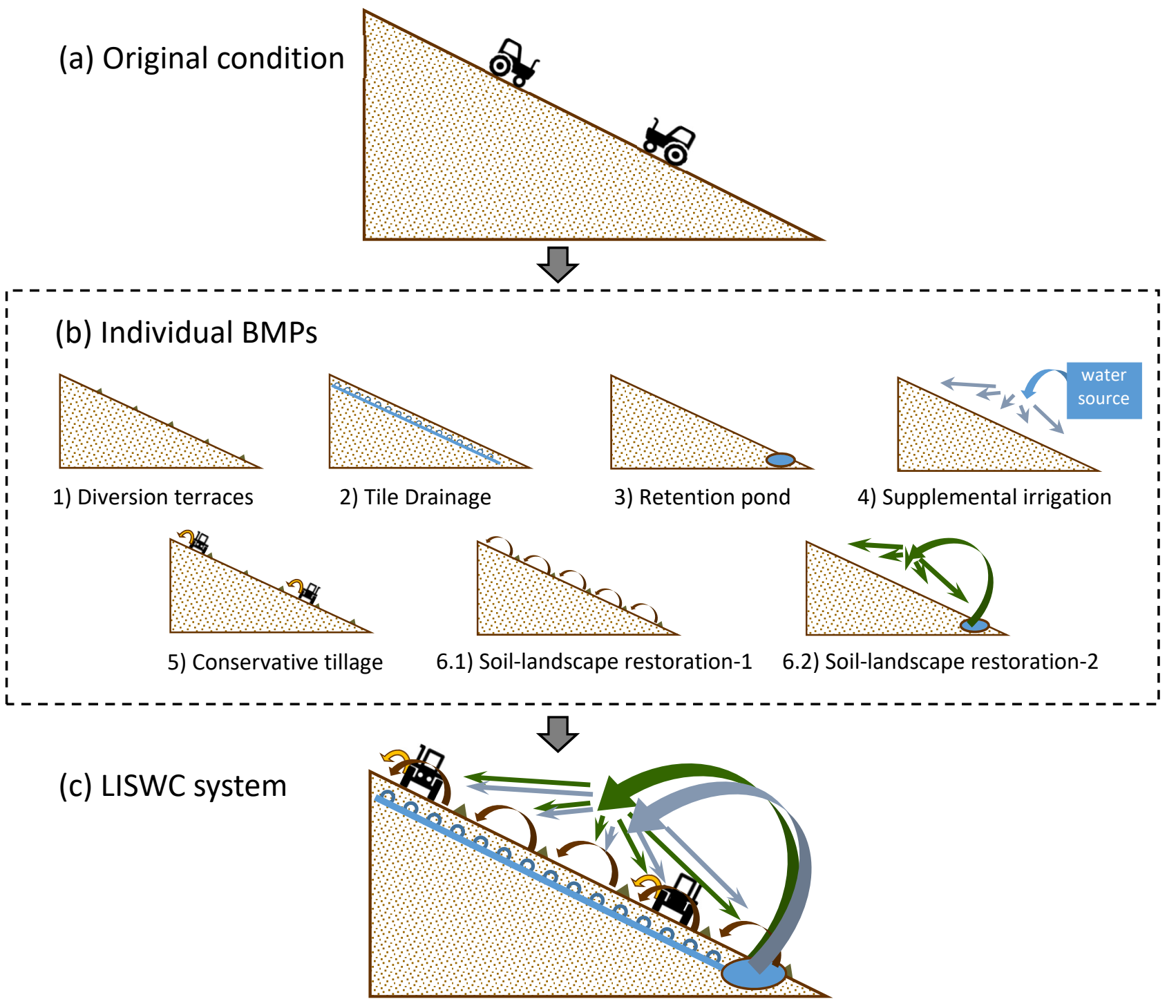

Figure 1. Illustration of the LISWC system on a sloping field.

Although these results are theoretical, they are based on solid understanding on individual BMPs and different landscape processes. Field experiment is underway to quantify the effects of LISWC on various aspects of soil, hydrology and crop growth, and the results will be published elsewhere. However, in this paper, we focus on presenting the LISWC as a conceptual model for solving the dilemma we face with soil and water conservation.

\section{Discussion}

\subsection{A holistic Landscape Perspective}

It is not rare for multiple BMPs to be used in the same field. For example, DTGW is in fact a combination of two BMPs, as its name implies. Additionally, wetlands, vegetative buffer strips, and reactive barriers have been widely used for drainage water management [71]. In particular, using a retention pond to store drainage water and then using 
the water for irrigation, a practice termed drainage water recycling, has been in practice for probably 30 years [72]. Moreover, at the watershed scale, multiple BMPs are often used to achieve the goal of water quality control at the watershed outlet [29]. However, in most cases, there is a lack of integration for multiple BMPs, especially from a holistic landscape perspective.

The knowledge on hydrology and soil erosion processes in the context of landscape are the foundation for integrating different BMPs in LISWC. For example, based on the knowledge of water erosion increasing downslope, diversion terraces are designed to stop the increase by blocking the flow and directing it into a grassed waterway. Building a retention pond at the bottom of the slope is based on the knowledge that both surface and subsurface flow, especially when enhanced by tile drainage, accumulate at the bottom of the slope so that water can be retained and stored there. Soil-landscape restoration is based on the knowledge on the locations of soil losses and depositions by both tillage and water erosion.

Another key aspect of the LISWC system is the holistic view of the landscape. This means treating soil and water as valuable resources. While they can be too much sometimes at some landscape positions (e.g., sediment in the retention pond and excess water in the soil profile), the solution should not be removing them out of the landscape whenever this happens. Instead, BMPs should be designed to store soil and water within the landscape as much as possible so that they can be used for another location or at another time. By conserving soil and water within the landscape, it not only reduces on-site soil degradation but also reduces off-site water contamination down the steam.

\subsection{LISWC Applied on Other Landforms and Larger Scales}

The example in the previous section focuses on LISWC on a rolling landform (characterized by long and steep linear slopes). However, the principle of LISWC can be applied to other types of landforms. For example, another common landform type in AC and northeast USA is the undulating landform [70]. The slope gradient on an undulating landform is lower than on a rolling landform, but an undulating landform usually features higher variations along the contour direction. Therefore, the design of LISWC must take these landscape characteristics into account. For example, due to the shorter and gentler slope on an undulating landform, water erosion is usually less than on a rolling landform. However, an undulating landform has higher slope curvature, especially along the contour direction so that its tillage erosion is higher. As a result, a diversion terrace may not be an effective BMP to control total soil erosion (because it reduces water erosion but increases tillage erosion) whereas soil-landscape restoration may be more effective. Additionally, because of the higher curvature in contour direction, it may be too difficult for tillage to operate (sharp turns) following the contour direction. Cross-slope tillage may be a more appropriate BMP. On the other hand, contour variation creates hollows, swales and low relief valleys. These landscape features are natural water converging areas. They can be utilized to form detention or retention structures, saving construction costs for building a retention structure at the bottom of the slope, such as on a rolling landform. They are also good locations for placing the major grassed waterways or main lines for the drainage tile network.

The principle of LISWC can also be applied at larger scales such as for a watershed or a region. In a watershed, the stream network not only defines the pathways for hydrology but also determines the spatial structure of the landform units. This information can be used to guide BMP design. For example, in an agricultural watershed, upland areas can be allocated mainly for agriculture with steep slopes protected by forest or pasture. Small dams can be established at the outlet of headwater subwatersheds. The reservoirs serve as retention ponds, retaining water, sediment and nutrients from upland agricultural area and the water can be used for supplemental irrigation. In lowland areas, especially depression areas close to the stream or its main branches, wetlands can be established or restored. Wetland with permanent water standing can function as a retention pond. It also adds 
biological diversity to the landscape. Along the stream, riparian zones can be established to filter out sediment and nutrients coming from upland areas. Vegetation in the riparian zone and some seasonal or event-based wetlands can be managed to enhance its filtering capacity. For example, willow trees can be grown in the riparian zone. Willow trees grow quickly and can take up excessive nutrients accumulated in the riparian zone. The willow trees can then be harvested and made into chips or biochar. The willow chips or biochar can be applied back to upland agricultural fields as soil modifier to increase soil carbon content and nutrient level.

It should be noted that the examples discussed in this paper are based on generic conditions. In designing the LISWC system for a specific site, the selection and placement of BMPs and the connections between these BMPs need to consider the local climate, soil, vegetation and topography conditions.

\subsection{Future Studies}

Although there is plentiful research on individual BMPs in the scientific literature, there is still a lack of detailed information, especially quantitative information for some BMPs on their effects. For example, although irrigation has been widely studied for potato production, most studies are carried out in dry regions where there is almost always a water deficit. In a humid climate region such as AC, precipitation is sufficient to meet crop water needs most of the time. There are only short periods of water deficit so that irrigation is only supplemental. On the other hand, there are also short periods of high precipitation so that there is a risk for over irrigation, resulting in a water excess condition for the soil. Due to this difference, the knowledge obtained from the dry region may not be applicable to humid regions and separate research needs to be carried out for supplemental irrigation in humid regions. Additionally, in a sloping field LISWC system, the retention structure can only hold a limited amount of water. Research is needed to understand the crop water needs throughout the growing season so that one can decide when to apply how much water in order to maximize the effects of the limited amount of water stored in the retention pond. Another example is soil-landscape restoration. Although a similar practice has been conducted a long time ago in history [73,74], using it as a BMP is relatively new. Research is needed to determine how much soil can be removed from the soil deposition areas and how much soil needs to be added to the soil loss areas. Additionally, possible side effects such as weed and pest spreading due to soil relocation also need to be examined. In particular, caution needs to be taken for returning sediments from the retention structure to the field as the texture and structure of the sediment likely will be different from the field soil due to the selective water erosion process, the disaggregation of soil granules and the preferential deposition of soil particles in different sizes. The sediment may also be enriched with nutrients and pollutants such as pesticides and heavy metals. Research is needed to evaluate the impacts of returning the sediments to the field on the soil's physical and chemical properties.

Compared to individual BMPs, the connections and interactions between individual BMPs is even less studied. Such connections and interactions could be a determining factor for the proper functioning of these BMPs, especially in a landscape or watershed setting. Understanding these connections and interactions is so important for an LISWC system because BMPs in an LISWC system are integrated. As such, the performance of one BMP will affect the performance of other BMPs, and the failure of one BMP may cause the failure of another BMP or even the entire LISWC system. For example, in a sloping field LISWC system such as the one discussed in the previous section, the DTGW will reduce surface runoff and water erosion, which will affect the amount of water the retention pond receives, which then will affect the amount of water available for irrigation and the amount of sediment that can be used for soil-landscape restoration. Supplemental irrigation and soil-landscape restoration will affect soil's long-term and short-term properties (e.g., soil texture and soil moisture content, respectively) and in turn, will affect the effectiveness of DTGW. How much these chain effects will eventually affect the performance of the LISWC 
is determined by many factors. Therefore, there is an urgent need to conduct research to fill these knowledge gaps to provide quantitative information on the connections and interactions between individual BMPs.

Another aspect of BMPs that is not well studied is their economics. Implementing many BMPs needs initial investment, sometimes a large amount, and there is often maintenance costs as well. The adoption of any BMP will be difficult if the cost outweighs the benefits economically. In an LISWC system, by connecting multiple BMPs, there is more potential for economic gains. For example, a retention pond alone will have almost no economic benefit, but by using the water for irrigation and returning fertile sediment back to the land, it has the potential to increase yield, and thus becomes economically beneficial. The flip side is that because there are more BMPs, the initial investment and maintenance cost will be higher. In addition, since the function of one BMP will rely on the performance of another BMP, the risk of system failure could be higher. Detailed economic studies are required to provide quantitative information on the overall economic performance of the LISWC system.

\section{Conclusions}

The landscape integrated soil and water conservation (LISWC) system is presented in this paper as a new paradigm for soil and water conservation in agricultural landscapes. The LISWC system is a system designed to conserve and reuse soil and water within the landscape by integrating multiple BMPs based on an understanding of the landscape processes and knowledge about the advantages and disadvantages of those BMPs. On a rolling landform field with a linear slope, an LISWC system can be established by integrating BMPs such as diversion terraces and grassed waterway systems, tile drainage, water retention structures, supplemental irrigation, conservative tillage practices and soillandscape restoration. Water and tillage erosion will be reduced by diversion terraces and grassed waterways and conservative tillage; field drainage conditions will be enhanced by tile drainage; runoff water will be stored in the retention structure and reused for irrigation; most eroded soil will be returned to the soil loss area via soil-landscape restoration. This holistic perspective can be used to develop LISWC systems for other landform types as well as at larger scales such as for a watershed or a region. Future studies are needed for individual BMPs, the connections and interactions between individual BMPs, and analysis on the overall economic benefit of an LISWC system.

Funding: This work was supported by Agriculture and Agri-Food Canada (AAFC) A-base projects "Landscape Integrated Soil and Water Conservation (LISWC) on sloping fields under potato production in Atlantic Canada" (\#J-001754, PI: Li) and "Characterizing and modeling the interactions between water and tillage erosion under potato and cereal production systems" (\#J-000994, PI: Li).

Acknowledgments: The author would like to thank David Lobb for his insight into landscape processes and soil and water conservation BMPs. It is through discussions with him that the initial thoughts of the LISWC system were formed. The author would also like to thank team members of the two projects, in particular, Yulia Kupriyanovich, Bonnie Robertson, Serban Danielescu, Louis-Pierre Comeau, Cameron Wagg and Fan-rui Meng for their valuable comments and suggestions.

Conflicts of Interest: The authors declare no conflict of interest.

\section{References}

1. Zelazny, V.E. (Ed.) Our Landscape Heritage: The Story of Ecological Land Classification in New Brunswick; New Brunswick Department of Natural Resources: Fredericton, NB, Canada, 2007.

2. DeMerchant, E.B. From Humble Beginnings: A Story of Agriculture in New Brunswick; New Brunswick Agriculture and Rural Development: Fredericton, NB, Canada, 1983.

3. Bohl, W.H.; Johnson, S.B. (Eds.) Commercial Potato Production in North America. In Potato Association of America Handbook; Second Revision of American Potato Journal Supplement Volume 57 and USDA Handbook 267 by the Extension Section of the Potato Association of America; 2010. Available online: http://www.whatcom.wsu.edu/ag/documents/seedpotatoes/ ProdHndbk_Final_000.pdf (accessed on 27 April 2021). 
4. NB-DAAF (The Government of New Brunswick, Department of Agriculture, Aquaculture and Fisheries). Agriculture and Agri-Food 2015. [NB]: Department of Agriculture, Aquaculture and Fisheries. Available online: http://www2.gnb.ca/content/dam/ gnb/Departments/10/pdf/Publications / Agr/ReviewAgriculture2015.pdf (accessed on 10 January 2018).

5. Chow, T.L.; Daigle, J.L.; Ghanem, I.; Cormier, H. Effects of potato cropping practices on water runoff and soil erosion. Can. J. Soil Sci. 1990, 70, 137-148. [CrossRef]

6. Chow, T.L.; Rees, H.W.; Monteith, J. Seasonal distribution of runoff and soil loss under four tillage treatments in the upper St. John River valley New Brunswick, Canada. Can. J. Soil Sci. 2000, 80, 649-660. [CrossRef]

7. Tiessen, K.; Li, S.; Lobb, D.A.; Mehuys, G.; Rees, H.; Chow, T. Using repeated measurements of 137Cs and modelling to identify spatial patterns of tillage and water erosion within potato production in Atlantic Canada. Geoderma 2009, 153, 104-118. [CrossRef]

8. Statistics Canada. Table 001-0014 1: Area, Production and Farm Value of Potatoes. 2017. Available online: https://www150 .statcan.gc.ca/t1/tbl1/en/tv.action?pid=3210035801 (accessed on 27 April 2021).

9. Bélanger, G.; Walsh, J.R.; Richards, J.E.; Milburn, P.H.; Ziadi, N. Yield response of two potato cultivars to supplemental irrigation and $\mathrm{N}$ fertilization in New Brunswick. Am. J. Potato Res. 2000, 77, 11-21. [CrossRef]

10. Carter, M.; Kunelius, H.; Sanderson, J.; Kimpinski, J.; Platt, H.; Bolinder, M. Productivity parameters and soil health dynamics under long-term 2-year potato rotations in Atlantic Canada. Soil Tillage Res. 2003, 72, 153-168. [CrossRef]

11. Zebarth, B.J.; Bélanger, G.; Cambouris, A.N.; Ziadi, N. Nitrogen fertilization strategies in relation to potato tuber yield, quality, and crop N recovery. In Sustainable Potato Production: Global Case Studies; He, Z., Larkin, R.P., Honeycutt, C.W., Eds.; Springer: New York, NY, USA, 2012; pp. 165-186.

12. Ochuodho, T.O.; Olale, E.; Lantz, V.A.; Damboise, J.; Chow, T.L.; Meng, F.; Daigle, J.L.; Li, S. Impacts of soil and water conservation practices on potato yield in northwestern New Brunswick, Canada. J. Soil Water Conserv. 2013, 68, 392-400. [CrossRef]

13. Environment and Climate Change Canada (ECCC). Historical Climate Data. 2019. Available online: http://climate.weather.gc.ca/ (accessed on 24 January 2019).

14. Lemmen, D.S.; Warren, F.J.; Lacroix, J.; Bush, E. (Eds.) From Impacts to Adaptation: Canada in a Changing Climate 2007; Government of Canada: Ottawa, ON, Canada, 2008; 448p.

15. Stocker, T.F.; Qin, D.; Plattner, G.K.; Alexander, L.V.; Allen, S.K.; Bindoff, N.L.; Bréon, F.M.; Church, J.A.; Cubasch, U.; Emori, S.; et al. Technical Summary. In Climate Change 2013: The Physical Science Basis. Contribution of Working Group I to the Fifth Assessment Report of the Intergovernmental Panel on Climate Change; Cambridge University Press: Cambridge, UK; New York, NY, USA, 2013.

16. Chow, T.L.; Rees, H.W.; Webb, K.T.; Langille, D.R. Modification of subsoil characteristics resulting from drainage tile installation. Soil Sci. 1993, 156, 346-357. [CrossRef]

17. Chow, T.L.; Rees, H.W.; Daigle, J.L. Effectiveness of terraces/grassed waterway systems for soil and water conservation: A field evaluation. J. Soil Water Conserv. 1999, 54, 577-583.

18. Bélanger, G.; Walsh, J.R.; Richards, J.E.; Milburn, P.H.; Ziadi, N. Nitrogen fertilization and irrigation affects tuber characteristics of two potato cultivars. Am. J. Potato Res. 2002, 79, 269-279. [CrossRef]

19. Yang, Q.; Benoy, G.A.; Chow, T.; Daigle, J.L.; Bourque, C.P.A.; Meng, F. Using the soil and water assessment tool to estimate achievable water quality targets through implementation of beneficial management practices in an agricultural watershed. $J$. Environ. Qual. 2012, 41, 64-72. [CrossRef]

20. Stuart, V. (Ed.) Watershed Evaluation of Beneficial Management Practices (WEBs): Managing our Land and Protecting Our Water through Long-Term Watershed-Scale Research: Final Report (2004-2013); Agriculture and Agri-Food Canada: Ottawa, ON, Canada, 2017.

21. Chow, L.; Rees, H.; Xing, Z. Impacts of long-term intensive potato production and conservation terraces/grassed waterway on runoff hydrology and soil quality. In Proceedings of the 19th World Congress of Soil Science: Soil Solutions for a Changing World, Brisbane, Australia, 1-6 August 2010; pp. 68-71.

22. Milburn, P.; Richards, J.E.; Gartley, C.; Pollock, T.; O’Neill, H.; Bailey, H. Nitrate Leaching from Systematically Tiled Potato Fields in New Brunswick, Canada. J. Environ. Qual. 1990, 19, 448-454. [CrossRef]

23. Xing, Z.; Chow, L.; Rees, H.W.; Meng, F.; Monteith, J.; Stevens, L. A comparison of effects of one-pass and conventional potato hilling on water runoff and soil erosion under simulated rainfall. Can. J. Soil Sci. 2011, 91, 279-290. [CrossRef]

24. Lobb, D.A. Understanding and managing the causes of soil variability. J. Soil Water Conserv. 2011, 66, 175A-179A. [CrossRef]

25. Margules, C.R.; Pressey, R.L. Systematic conservation planning. Nature 2000, 405, 243-253. [CrossRef] [PubMed]

26. Margules, C.R.; Pressey, R.L.; Williams, P.H. Representing biodiversity: Data and procedures for identifying priority areas for conservation. J. Biosci. 2002, 27, 309-326. [CrossRef]

27. Kukkala, A.S.; Moilanen, A. Core concepts of spatial prioritization in systematic conservation planning. Biol. Rev. 2013, 88, 443-464. [CrossRef] [PubMed]

28. Tomer, M.D.; Sadler, E.J.; Lizotte, R.E.; Bryant, R.B.; Potter, T.L.; Moore, M.T.; Veith, T.L.; Baffaut, C.; Locke, M.A.; Walbridge, M.R. A decade of conservation effects assessment research by the USDA Agricultural Research Service: Progress overview and future outlook. J. Soil Water Conserv. 2014, 69, 365-373. [CrossRef]

29. Li, S.; Elliott, J.A.; Tiessen, K.H.D.; Yarotski, J.; Lobb, D.A.; Flaten, D.N. The Effects of Multiple Beneficial Management Practices on Hydrology and Nutrient Losses in a Small Watershed in the Canadian Prairies. J. Environ. Qual. 2011, 40, 1627-1642. [CrossRef] [PubMed]

30. Srivastava, P.; Hamlett, J.M.; Robillard, P.D.; Day, R.L. Watershed optimization of best management practices using AnnAGNPS and a genetic algorithm. Water Resour. Res. 2002, 38, WR000365. [CrossRef] 
31. Maringanti, C.; Chaubey, I.; Popp, J. Development of a multiobjective optimization tool for the selection and placement of best management practices for nonpoint source pollution control. Water Resour. Res. 2009, 45, W06406. [CrossRef]

32. Rodriguez, H.G.; Popp, J.; Maringanti, C.; Chaubey, I. Selection and placement of best management practices used to reduce water quality degradation in Lincoln Lake watershed. Water Resour. Res. 2011, 47, W01507. [CrossRef]

33. Zimmerman, E.K.; Tyndall, J.C.; Schulte, L.A. Using Spatially Targeted Conservation to Evaluate Nitrogen Reduction and Economic Opportunities for Best Management Practice Placement in Agricultural Landscapes. Environ. Manag. 2019, 64, 313-328. [CrossRef]

34. Tomer, M.D.; Locke, M.A. The challenge of documenting water quality benefits of conservation practices: A review of USDAARS's conservation effects assessment project watershed studies. Water Sci. Technol. 2011, 64, 300-310. [CrossRef] [PubMed]

35. Milne, G. Some suggested units of classification and mapping, particularly for East African soils. Soil Res. 1935, 4, 183-198.

36. Pennock, D.; Corre, M. Development and application of landform segmentation procedures. Soil Tillage Res. 2001, 58, 151-162. [CrossRef]

37. Morgan, R.P.C. Soil Erosion and Conservation, 3rd ed.; Blackwell Publishing: Malden, MA, USA; Oxford, UK; Carlton, Australia, 2005; ISBN 978-1-4051-1781-4.

38. Li, S.; Lobb, D.A.; Lindstrom, M.J.; Farenhorst, A. Patterns of tillage and water erosion on topographically complex landscapes in the North America Great Plains. J. Soil Water Conserv. 2008, 63, 37-46. [CrossRef]

39. Govers, G.; Lobb, D.A.; Quine, T.A. Preface-tillage erosion and translocation: Emergence of a new paradigm in soil erosion research. Soil Tillage Res. 1999, 51, 167-174.

40. Van Oost, K.; Govers, G.; De Alba, S.; Quine, T.A. Tillage erosion: A review of controlling factors and implications for soil quality. Prog. Phys. Geogr. 2006, 30, 443-466. [CrossRef]

41. Li, S.; Lobb, D.A.; Tiessen, K.H.D. Soil erosion and conservation. In Encyclopedia of Environmetrics, 2nd ed.; El-Shaarawi, A.-H., Piegorsch, W., Eds.; John Wiley \& Sons Ltd.: Chichester, UK, 2012; pp. 2505-2512.

42. Huffman, R.L.; Fangmeier, D.D.; Elliot, W.J.; Workman, S.R. Soil and Water Conservation Engineering, 7th ed.; American Society of Agricultural and Biological Engineers: St. Joseph, MI, USA, 2013; ISBN 1-892769-86-7.

43. Yang, Q.; Zhao, Z.; Benoy, G.; Chow, T.L.; Rees, H.W.; Bourque, C.P.-A.; Meng, F.-R. A Watershed-scale Assessment of CostEffectiveness of Sediment Abatement with Flow Diversion Terraces. J. Environ. Qual. 2010, 39, 220-227. [CrossRef]

44. Yang, Q.; Meng, F.; Zhao, Z.; Chow, T.; Benoy, G.; Rees, H.W.; Bourque, C.P.A. Assessing the impacts of flow diversion terraces on stream water and sediment yields at a watershed level using SWAT model. Agric. Ecosyst. Environ. 2009, 132, 23-31. [CrossRef]

45. Li, S.; Lobb, D.A.; Tiessen, K.H. Modeling tillage-induced morphological features in cultivated landscapes. Soil Tillage Res. 2009, 103, 33-45. [CrossRef]

46. Nowland, J.L. The agricultural productivity of the soils of the Atlantic Provinces. In Monograph No. 12, Research Branch; Agriculture Canada: Ottawa, ON, Canada, 1975; p. 19.

47. Madramootoo, C.A.; Johnston, W.R.; Ayars, J.E.; Evans, R.O.; Fausey, N.R. Agricultural drainage management, quality and disposal issues in north America. Irrig. Drain. 2007, 56, S35-S45. [CrossRef]

48. Stark, J.C.; Love, S.L. (Eds.) Potato Production Systems: A Comprehensive Guide for Potato Production; University of Idaho Center for Potato Research and Education: Moscow, ID, USA, 2003.

49. Milburn, P.; Gartley, C. Subsurface drainage and land use in New Brunswick. Can. Agric. Eng. 1988, 30, $13-17$.

50. Ritter, F.; Rudra, R.P.; Milburn, P.H.; Prasher, S. Drainage and Water Quality in Northern United States and Eastern Canada. J. Irrig. Drain. Eng. 1995, 121, 296-302. [CrossRef]

51. Fraser, H.; Fleming, R. Environmental Benefits of Tile Drainage-Literature Review: Land Improvement Contractors of Ontario, 23p. 2001. Available online: https:/ / www.ridgetownc.com/research/documents/fleming_drainage.pdf (accessed on 20 December 2020).

52. Milburn, P.; Richards, J.E. Nitrate concentration of subsurface drainage water from a corn field in southern New Brunswick. Can. Agric. Eng. 1994, 36, 69-78.

53. Ayars, J.E.; Grismer, M.E.; Guitjens, J.C. Water Quality as Design Criterion in Drainage Water Management Systems. J. Irrig. Drain. Eng. 1997, 123, 154-158. [CrossRef]

54. Bottcher, A.B.; Monke, E.J.; Huggins, L.F. Nutrient and Sediment Loadings from a Subsurface Drainage System. Trans. Am. Soc. Agric. Eng. 1981, 24, 1221-1226. [CrossRef]

55. Chapman, A.; Foster, I.; Lees, J.; Hodgkinson, R.; Jackson, R. Particulate phosphorus transport by sub-surface drainage from agricultural land in the UK. Environmental significance at the catchment and national scale. Sci. Total Environ. 2001, 266, 95-102. [CrossRef]

56. Chapman, A.S.; Foster, I.D.L.; Lees, J.A.; Hodgkinson, R. Sediment sources and transport pathways in the Rosemaund experimental catchment, Herefordshire, UK. Hydrol. Process. 2005, 19, 2875-2897. [CrossRef]

57. Boardman, J.; Foster, I.D.L. Run-off and sediment storage: The effectiveness of mitigation measures against soil erosion and freshwater pollution. Land Degrad. Dev. 2021, 32, 2453-2455. [CrossRef]

58. Ayars, J.E.; Evans, R.G. Subsurface drainage-what's next. Irrig. Drain. 2015, 64, 378-392. [CrossRef]

59. Winer, R. National Pollutant Removal Database for Stormwater Treatment Practices, 3rd ed.; Center for Watershed Protection: Ellicott City, MD, USA, 2007. 
60. Chrétien, F. Impacts of stormwater treatment and flow regulation ponds on hydrology and water quality. In Report of AAFC In-house Projects: Climate Adaptation for Resiliency in Agriculture/Environmental Impacts of Peak Flows and Projected Mitigation Measures at the Agricultural Watershed Scale; 2014. Available online: http://coordination-sc.org/wp-content/uploads/Report_12303E_ Stormwater_Treatment_Flow_Regulation_Ponds.pdf (accessed on 27 April 2021).

61. Tiessen, K.H.D.; Elliott, J.A.; Stainton, M.; Yarotski, J.; Flaten, D.N.; Lobb, D.A. The effectiveness of small-scale headwater storage dams and reservoirs on stream water quality and quantity in the Canadian Prairies. J. Soil Water Conserv. 2011, 66, 158-171. [CrossRef]

62. King, B.A.; Stark, J.C. Potato Irrigation Management; Bulletin No. 789; University of Idaho Extension: Moscow, Idaho, 1997.

63. Wagg, C.; Hann, S.; Kupriyanovich, Y.; Li, S. Timing of short period water stress determines potato plant growth, yield and tuber quality. Agric. Water Manag. 2021, 247, 106731. [CrossRef]

64. Boardman, J.; Burt, T.; Foster, I. Monitoring soil erosion on agricultural land: Results and implications for the Rother valley, West Sussex, UK. Earth Surf. Process. Landf. 2020, 45, 3931-3942. [CrossRef]

65. Buckingham, F. Fundamentals of Machine Operation: Tillage; John Deere Service Publications Department: Moline, IL, USA, 1976.

66. Lal, R. Tillage effects on soil degradation, soil resilience, soil quality, and sustainability. Soil Tillage Res. 1993, 27, 1-8. [CrossRef]

67. Tiessen, K.; Lobb, D.; Mehuys, G.; Rees, H. Tillage translocation and tillage erosivity by planting, hilling and harvesting operations common to potato production in Atlantic Canada. Soil Tillage Res. 2007, 97, 123-139. [CrossRef]

68. Manitoba Agriculture, Food and Rural Initiatives (MAFRI). Soil Management Guide; 2008; pp. 91-97. Available online: https: //www.gov.mb.ca/agriculture/environment/soil-management/soil-management-guide/pubs/soil-management-guide.pdf (accessed on 27 April 2021).

69. Papiernik, S.; Schumacher, T.; Lobb, D.; Lindstrom, M.; Lieser, M.; Eynard, A.; Schumacher, J. Soil properties and productivity as affected by topsoil movement within an eroded landform. Soil Tillage Res. 2009, 102, 67-77. [CrossRef]

70. Soil Classification Working Group (SCWG). The Canadian System of Soil Classification; Agriculture and Agri-Food Canada: Ottawa, ON, Canada, 1998; 187p.

71. Strock, J.S.; Kleinman, P.J.; King, K.W.; Delgado, J.A. Drainage water management for water quality protection. J. Soil Water Conserv. 2010, 65, 131A-136A. [CrossRef]

72. Frankenberger, J.; Allred, B.; Gamble, D.; Baule, W.J.; Brown, L. On-Farm Water Recycling as an Adaptation Strategy for Drained Agricultural Land. In Proceedings of the ASABE 1st Climate Change Symposium: Adaptation and Mitigation Conference Proceedings, Chicago, IL, USA, 3-5 May 2015. [CrossRef]

73. Mielke, L.N.; Schepers, J.S. Plant response to topsoil thickness on an eroded loess soil. J. Soil Water Conserv. 1986, $41,59-63$.

74. Massee, T.W. Simulated Erosion and Fertilizer Effects on Winter Wheat Cropping Intermountain Dryland Area. Soil Sci. Soc. Am. J. 1990, 54, 1720-1725. [CrossRef] 